A comprehensive investigation of the critical factors influencing knowledge management strategic alignment

\author{
Mona Jami Pour \\ Hazrat-e Ma'soumeh University (HMU), Iran \\ Hasan Zarei Matin \\ Hamid Reza Yazdani \\ Zahra Kouchak Zadeh \\ University of Tehran, Iran
}

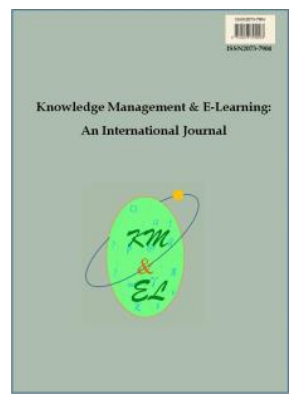

Knowledge Management \& E-Learning: An International Journal (KM\&EL) ISSN 2073-7904

Recommended citation:

Jami Pour, M., Matin, H. Z., Yazdani, H. R., \& Kouchak Zadeh, Z. (2019). A comprehensive investigation of the critical factors influencing knowledge management strategic alignment. Knowledge Management \& E-Learning, 11(2), 215-232. https://doi.org/10.34105/j.kmel.2019.11.011 


\title{
A comprehensive investigation of the critical factors influencing knowledge management strategic alignment
}

\author{
Mona Jami Pour* \\ Department of Management \\ Hazrat-e Ma'soumeh University (HMU), Iran \\ E-mail: monajami@ut.ac.ir
}

\section{Hasan Zarei Matin}

Faculty of Management and Accounting

College of Farabi

University of Tehran, Iran

E-mail: matin@ut.ac.ir

\section{Hamid Reza Yazdani}

Faculty of Management and Accounting

College of Farabi

University of Tehran, Iran

E-mail: hryazdani@ut.ac.ir

\section{Zahra Kouchak Zadeh}

Faculty of Management and Accounting

College of Farabi

University of Tehran, Iran

E-mail: kouchakzade@ut.ac.ir

*Corresponding author

\begin{abstract}
Despite the huge investment in Knowledge Management (KM) initiatives by many organizations, KM projects are facing a high failure rate. One of the main reasons is the lack of alignment between business and KM strategies. This study aims to identify and prioritize the factors affecting strategic alignment between business and KM strategies. A comprehensive literature review integrated with the focus group method was used to identify and classify effective factors of KM strategic alignment. Next, a survey method was conducted to evaluate and prioritize the extracted factors suggested by the experts. Further, the sign test was used to analyze the priorities of these factors using Shannon's entropy method. The results reveal that the key factors affecting strategic alignment between business strategies and KM include knowledge-based culture, KM governance, and strategic approach to KM, communication between KM and business, top management support, human resource capabilities, environmental and competitive factors and IT management capabilities. The findings provide a comprehensive KM-business strategic framework.
\end{abstract}


Keywords: Knowledge management; KM; Strategic alignment; KM-business strategic alignment

Biographical notes: Mona Jami Pour has Ph.D. of Information System Management in Faculty of Management at University of Tehran. Her research interests mainly are in social media, information systems, Knowledge management, strategic alignment, virtual organization. She received her MA in information technology management from the University of Tehran. She has published several articles in scientific journal and international conference proceedings.

Hassan Zarei Matin is a Full professor of management in university of Tehran. His main field of interests and researches are in the organizational culture, organizational behaviour and social capital. He has published many articles in scientific journal and international conference proceedings as well.

Hamid Reza Yazdani is an Assistant Professor in the College of Farabi, The University of Tehran. He has been involved in multiple disciplinary research in the areas of KM, Human resource (HR), organizational development.

Zahra Kouchak Zadeh has M.A of Information System from the University of Tehran. Her research interests are KM, strategic planning, strategic alignment, and IT governance.

\section{Introduction}

As the world changes rapidly and business environment becomes more and more complex, knowledge turns to be a strategic source for organizations to achieve competitive advantage and productivity in a business environment (Wu, Chen, Fang, \& Sung, 2015; Wang, Ding, Liu, \& Li, 2016), and also create value (Grant, 1996). Therefore, KM has become an important priority for managers (Ale, Toledo, Chiotti, \& Galli, 2014) and the primary task of the management is to establish the coordination required for knowledge integration in organizations (Grant, 1996). Executives are aware of the strategic advantage of implementing $\mathrm{KM}$ in their organizations and therefore, investments in KM technologies arise increasingly in recent years (Wang et al., 2016). Many organizations have initiated KM projects to exploit the organization's largest asset (Zack, 2002). In American Productivity and Quality Center's (APQC) report about KM investments and their priorities, it is clarified that more than 93\% of 524 studied companies allocated particular budget to KM projects (APQC, 2015), and KM investments are increasing as before (Rhem, 2015). The KM market value was about 206,900 million USD in 2016 and it is expected to increase more than $22 \%$ between 2017 and 2025 (Zion Market Research, 2018).

Despite the increasing attention towards the implementation of these new initiatives, the high failure rate is reported ranged from $50 \%$ to $80 \%$. Some studies have been conducted regarding the KM challenges and barriers (Akhavan, Reza Zahedi, \& Hosein Hosein, 2014; Jennex \& Olfman, 2010), and suggested some reasons for the KM failures like excessive emphasis on information technology (IT), lack of KM strategies, lack of KM strategic alignment (Turner, Biros, \& Moseley, 2009; Jami Pour, Kouchak Zadeh, \& Ahmad Zadeh, 2018), inappropriate strategies and disregarding KM outcomes (Zack, 2002; Rhem, 2015; López-Nicolás \& Meroño-Cerdán, 2011; Beiryaei \& Jamporazmay, 2010). Smith, Mills, and Dion (2010) stated that shortcoming and failures 
of KM projects can be addressed by linking KM to business strategy. Changing business models, the transformation of organizations, and rapid changes in customer demands have increasingly revealed the need for aligning knowledge and business (Akram, Mehmood, \& Khan, 2015). Dayan, Heisig, and Matos (2017) believed that KM can lead to organizational effectiveness when it is aligned with business strategy.

Several studies have confirmed the positive impact of KM strategic alignment on organizational performance (Kekwaletswe \& Mathebula, 2014; Al-Ammary, 2014; Chen \& Huang, 2010). KM strategic alignment has been considered as the key solution to KM productivity paradox due to some confirmed business values like its impact on innovation (Choe, 2014), empowering organizations to acquire their required knowledge aligned with the firm's vision, goals, strategies and plans (Asoh, Belardo, \& Duchessi, 2008), and improving performance (Chen \& Huang, 2010). Many researchers suggested a new wave of KM domain which focuses on such critical issues as assessing strategic intention of KM initiatives, identifying critical knowledge domains, linking KM spending to business imperatives (Dayan et al., 2017), and increasing the importance of strategy in KM (Bosua \& Venkitachalam, 2013). Dayan et al. (2017) investigated the strategic role of KM in articulating and implementing organizational strategies. They found that about $41 \%$ of respondents considered the relation between $\mathrm{KM}$ and the business strategy as highly important.

As mentioned by Ale et al. (2014), one of the prerequisites of successful KM implementation is comprehensively understanding the main factors affecting KMbusiness strategic alignment which helps managers to define strategies and guidelines and govern implementation process. Dayan et al. (2017) surveyed 222 KM experts' opinions about the relationship between KM and strategic management. Their results showed that the majority of participants recommended future research about KM and business strategies linkage and considered it as highly important. Despite the importance of KM strategic alignment (Asoh, 2004; Tseng, 2008; Abou-Zeid, 2009; Ale et al., 2014; Dayan et al., 2017; Centobelli, Cerchione, \& Esposito, 2018), few studies have examined drivers of aligning KM strategies with business strategies. Aktürk and Kurt (2016) identified the relationship between KM practices and strategy formulation capabilities. They just examined the relationship between these two constructs and did not point out KM alignment. Unlike the IS/IT fields, where alignment is one of the five top topics in literature (Walsh \& Renaud, 2017), and significant work has been done on IT-business alignment, our literature review revealed the lack of alignment studies in the KM field which identify and prioritize most important factors influencing KM-business strategic alignment. Most of the researches in KM alignment were applied quantitative methods and investigated the relationships between different types of KM alignment and other constructs such as business performance (Chen, Huang, \& Liu, 2007; Wu et al., 2015; Asoh, 2004), KM effectiveness (Shih \& Chiang, 2005), and innovation (Choe, 2014). There are few studies which explore KM strategic alignment enablers qualitatively. Therefore, the main purpose of the study is to explore KM-business strategic alignment key drivers which must be considered to implement KM initiatives successfully and gain competitive advantage. 


\section{Literature review}

\subsection{Knowledge and knowledge management (KM)}

Davenport and Prusak's (1998) definition of knowledge is a mix of framed experience, values, contextual information, expert insight, and grounded intuition that provides an environment and framework for evaluating and incorporating new experiences and information (Davenport \& Prusak, 1998; Shafiei Nikabadi, Bagheri, \& MohammadiHoseini, 2016). Knowledge is a valuable collection of information available to be used in decision-making practices (Chang \& Lin, 2015; Marques et al., 2019).

Tessier and Dalkir (2016) considered KM as a generic process through which organizations generate value from knowledge. It has now turned into a strong condition for the survival of dynamic and innovative organizations; even business and market competitiveness depend upon acquisition, development, and application of individual and organizational knowledge (Chen \& Huang, 2010). KM is considered as a more important issue than knowledge itself (Emerson \& Berge, 2018). In other definition, it is the process of identification, creation, absorption, and application of organizational knowledge to exploit new opportunities and improve performance is called KM (Abu Bakar, Yusof, Tufail, \& Virgiyanti, 2016).

\subsection{KM strategic alignment}

As KM is placed in the area of Information System (IS) (Jamporazmey \& Mehrafrouz, 2012), and few studies have been conducted on KM strategic alignment, the more general literature on IT/IS is then utilized. Therefore, the discussion continues with IT alignment and finally ends with KM strategic alignment. IT-business alignment topic is among the top five IS issues. The Society for Information Management (SIM) conducted the survey about most concerns of chief information officers (CIO) and found that strategic alignment has been considered as one of the three challenges or major priorities facing IT managers (Luftman et al., 2013; Preston, 2014). The integration of IT investment and business requirements to maximize the value of IT is called strategic alignment (ElMekawy, Rusu, \& Perjons, 2015). New IT basically changes traditional business strategy and if firms fail to respond to rapid environmental changes due to the inflexibility of the relationship between IT and business, this may lead to their failure and prevent them from achieving their goals. Therefore, a certain level of organizational alignment is required (Coltman, Tallon, Sharma, \& Queiroz, 2015). Many studies were conducted about IT-business strategic alignment by IS practitioners and academics. Table 1 show some researches about effective factors of IT-business alignment or dimensions of it.

The purpose of aligning KM strategy with business strategy is to influence the organizational performance which is supported by various studies (Wu et al., 2015; Chen \& Huang, 2012; Asoh, 2004). Today, managing knowledge has become an important task for organizations and the first requirement for the successful implementation of its projects is the alignment between KM and business strategies (Zack, 2002; Ale et al., 2014; Alaceva \& Rusu, 2015). Asoh (2004) defined KM strategic alignment as the degree of integration of KM strategies and business strategies to meet business knowledge requirement. KM-business strategic alignment has been considered as "the degree to which KM mission, objectives and plans support the business mission, objectives, and plans" (Ale et al., 2014). Most KM projects ignore the vital role of strategic alignment and they are planned independently of business strategies (Jami Pour, Manian, \& Yazdani, 2016). Strategic KM-business alignment is considered as the missing link in 
knowledge management research (Asoh, 2004). Zack (2002) has proposed KM SWOT model (Knowledge Management Strengths, Weaknesses, Opportunities, and Threats) as a way for aligning knowledge with business strategy. Zack (2002) believed that KM SWOT aligns KM initiatives with competitive strategies by helping businesses to identify the knowledge gap (the gap between what an organization must know and what it actually knows) and the strategic gap (the gap between what an organization must do and what it can do to compete).

Table 1

Some of the related studies related to IT-business strategic alignment factors

\begin{tabular}{ll}
\hline \multicolumn{1}{c}{ Author (s) } & \multicolumn{1}{c}{ Effective Factors/dimensions } \\
\hline Luftman (2000) & $\begin{array}{l}\text { Communications, competence/value measurement, governance, partnership, scope, and } \\
\text { architecture, skills } \\
\text { CEO commitment to IT, IT sophistication, external IT expertise }\end{array}$ \\
Hussin et al. (2002) & $\begin{array}{l}\text { Shared domain knowledge, planning sophistication, prior IS success, organizational size, } \\
\text { environmental uncertainty }\end{array}$ \\
Chan et al. (2006) & $\begin{array}{l}\text { Sharing knowledge between business and IT technical people, maintaining IT belief in } \\
\text { business executive/managers }\end{array}$ \\
Johnson \& Lederer (2010) & $\begin{array}{l}\text { The relationship between business and IT executives, the alignment direction } \\
\text { IT flexibility, IT capability, communication effectiveness, strategic information systems } \\
\text { planning (SISP) } \\
\text { Communication, shared domain knowledge, IT success, organizational size, IT } \\
\text { management sophistication, planning sophistication, communication }\end{array}$ \\
Charoensuk et al. (2014) & $\begin{array}{l}\text { Planning IT and business, the relationship between business and IT executives, the } \\
\text { success of IT implementation, areas of shared knowledge }\end{array}$ \\
\hline
\end{tabular}

Considering Henderson and Venkatraman's model (1993), Abou-Zeid (2009) developed a strategic alignment model for KM that includes the external domain $(\mathrm{K}$ scope, K-systematic competencies, and K-governance) and internal domain (Kinfrastructures, K-processes, and K-skills). Majority of the KM strategic alignment literature examined the relationship between the alignment of KM strategy and other enterprise strategies (like business strategy, IT strategy, human resource strategy), and business performance or KM effectiveness. (Asoh, 2004; Franken \& Braganza, 2006; AlAmmary \& Fung, 2008; Chen, Yeh, \& Huang, 2012). For example, Chen and Huang (2012) investigated the relationship between the alignment of KM strategy, Human Resource Management (HRM) strategy and IT strategy with a business performance like $\mathrm{Wu}$ et al. (2015). Smith et al. (2010) examined a model that linked business strategy and KM capabilities with organizational effectiveness. They stated that business strategy is a key driver of KM capabilities and, both business strategy and KM capabilities impact organizational effectiveness. Chen et al. (2007) found that alignment between four strategies including business strategy, IT strategy, KM strategy, and HRM strategy enhanced business performance. Asoh (2004) examined the relationship between the alignment of business-related strategy and knowledge-related strategy with organizational performance. Shih and Chiang (2005) examined the relationships between corporate strategy, HRM strategy, and KM strategy, as well as their interactive impact on KM effectiveness. Bosua and Venkitachalam (2013) proposed a framework for aligning KM strategies and processes. Their strategic-workgroup alignment framework explores key alignment enablers and different approaches to align KM strategy and KM processes. Choe (2014) investigated the different kinds of innovations generated according to the 
KM-business strategic alignment. He found that when a cost leadership strategy is aligned with exploratory KM strategy, the process innovation is more encouraged and when differentiation strategy is aligned with exploitative KM strategy, product innovation is increased.

On the other hand, some studies examined different aspects of KM strategic alignment; for instance, Bosua and Venkitachalam (2013) explored alignment between KM strategies and KM processes; in another study, Centobelli et al. (2018) introduced a methodology to align enterprise knowledge and knowledge management systems. They developed a software-based Decision Support System (DSS) which allows managers to evaluate KM processes and identify which KMSs are aligned with the nature of the knowledge. Summarily, some criticisms have been made regarding KM strategic alignment researches. Firstly, the majority of the researches did not consider various dimensions of KM strategic alignment simultaneously. Some of them only noted technological consideration to achieve alignment (Centobelli et al., 2018), and some other researches mentioned process considerations to attain KM alignment (Bosua \& Venkitachalam, 2013). Secondly, most of the previous researches tried to examine relational models of KM alignment which consisted of the relationships between KM strategy and other business strategies with business performance or KM effectiveness. 3 . Finally, they disregarded to identify how to enhance the alignment and which factors influence KM strategic alignment. Identifying effective factors of KM strategic alignment and prioritizing implementation of them are somewhat ignored in KM literature.

Considering these theoretical gaps, this research tries to develop a comprehensive framework for KM-business strategic alignment. Since KM is considered as a subset of IS domain (Gable, 2010; Guo \& Sheffield, 2008), therefore, this study reviewed the literature of IS/ IT strategic alignment, in general, and KM, in particular, to identify the key drivers of KM strategic alignment.

\section{Methodology}

\subsection{Instruments}

The term strategic alignment has been regarded as one of the most important topics in IS literature and recently has been paid much attention in $\mathrm{KM}$ ( $\mathrm{Wu}$ et al., 2015). Understanding the enablers of KM strategic alignment comprehensively is vital for defining implementation strategies and guidelines which is the main purpose of this study. Therefore, the main question of the research is: Which are the main effective factors and drivers of KM strategic alignment? What is the priority and importance of the effective factors of KM strategic alignment?

To answer these questions, the mixed method approach was applied. Given the exploratory nature of this study, in the first step, a comprehensive literature review is conducted along with the qualitative method of focus group to explore KM strategic alignment drivers. Focus group method is a type of qualitative method to obtain data which is also unique in that it allows data collection both from the individual and from the individual as a part of a larger group as the unit of analysis (Massey, 2011). We invited six experts in strategic $\mathrm{KM}$ to participate in focus group discussion meeting to enrich the factors and measures and, also to improve the classification of them. The focus group method was used to integrate a wide range of participants' concerns and viewpoints trying to identify a comprehensive list of KM alignment drivers. 
The majority of the researches about focus groups advised the use of this method along with other methods, such as surveys. In this study, we used a multi-method approach to increase the validity of the research. And in the second step, a quantitative survey method is used to evaluate and prioritize the extracted drivers and measures via experts' viewpoints. Two different types of surveys were introduced according to the span of time needed to complete the survey: Cross-sectional and longitudinal. In this study, a cross-sectional survey was applied and the data gathering process was performed at a single period of time. The questionnaire consisted of two parts: In the first part of the questionnaire, the participants were asked to validate the factors and their measures via a 5-point Likert scale ranging from strongly agree to strongly disagree. The second part included questions about the priority of factors and measures using a 5-point Likert scale ranging from very important to less important. After repeated follow-ups and continuous tracing, 64 questionnaires were collected for 2 months.

\subsection{Reliability and validity}

In the first step, in order to guarantee the reliability of the focus group, the approach was designed in such way that it approximates as closely as completeness as suggested by Chioncel, Van Der Veen, Wildemeersch, and Jarvis (2003). The focus group questions were clarified which led to relevant answers to the research and ensured that it is repeatable. The time frame was clearly identified which is one of the aspects of focus group design. Variety of participants also increased the reliability of the research. KM and KM strategic planning academics and practitioners were invited to participate in focus group discussions. Chioncel et al. (2003) noted that variety guarantees the reliability of the focus group that means participants must be able to provide a whole range of responses to the research questions. In order to enhance the validity of focus group, we tried to select participants that were competent to answer the research questions. They had appropriate practical experiences or academic expertise. All focus group discussions were recorded for more descriptive and interpretative validity.

Reliability of the questionnaire was assessed using Cronbach's alpha via a pretest survey and results showed that the reliabilities of each construct exceed 0.7. Cronbach's $\alpha$ values of the eight factors were $0.861,0.772,0.85,0.763,0.91,0.894,0.887$, and 0.891 respectively. To ensure the validity of the questionnaire, the content validity method was used which is most often addressed in academic papers. This type of validity can help to ensure construct validity and give confidence to audiences about the instrument (Yaghmale, 2009). By studying the related sources, a preliminary questionnaire was designed and reviewed by four experts. Some changes were suggested, and the final questionnaire was prepared after applying the given changes.

\subsection{Research sample and method of analysis}

In the first step, six strategic KM experts included three academics in the field of KM strategic planning, KM implementation, and KM alignment with more than five scientific and valuable articles and three CKOs with more than seven years of practical experiences in these fields. All discussions were recorded and carefully documented by the authors. Data gathered from focus group were analyzed by content analysis method. In the second step of the study, the research population comprised experts in KM including faculty members, practitioners, KM project managers, organizational CKOs and KM specialists who have more than 4 years' experience in KM implementation or more than 5 years' experience in KM. Using Snowball technique, a sample of 64 members was selected to 
participate in the study. Data gathered from the survey questionnaire were analyzed by two methods regarding the two parts of the questionnaire. The sign test was used for validation of measures and Shannon's entropy technique was used for determining the priority of factors and measures. Entropy is a multi-criteria decision-making method. It indicates the degree of uncertainty in the content of a message and the main idea in this method is that as much as the distribution of values of a measure is greater, the more important that measure would be (Zhao, Qiu, \& Liu, 2010).

\section{Findings}

Step 1. After comprehensive reviewing and conducting focus group method, eight factors were extracted from deep discussions during the focus group meeting which include: KM governance, top management support, KM-business communications, competitive factors, knowledge-friendly culture, IT sophistication, strategic attitude towards KM and skills. Table 2 shows the extracted factors of KM strategic alignment. During the focus group meeting, the classification of the measures was discussed and improved. As shown in Table 2, most of the measures are cited both in the literature and focus group discussions as drivers for KM strategic alignment.

\section{Table 2}

Effective factors of KM strategic alignment and their related measures

\begin{tabular}{|c|c|c|c|}
\hline Factors & Measures & References & $\begin{array}{l}\text { Results of } \\
\text { focus group }\end{array}$ \\
\hline \multirow[t]{5}{*}{ KM governance } & $\begin{array}{l}\text { Definition of the role of knowledge chief } \\
\text { officer }(\mathrm{CKO}) \text { in organization }\end{array}$ & $\begin{array}{l}\text { Abou-Zeid (2009); Akhavan et al. } \\
\text { (2009); Kannabiran \& Pandyan (2010); } \\
\text { Chen \& Fong (2012); Al-Ammary } \\
\text { (2014) }\end{array}$ & $*$ \\
\hline & Establishment of the KM team or organization & $\begin{array}{l}\text { Akhavan et al. (2009); Schroeder et al. } \\
\text { (2012); Chen \& Fong (2012) }\end{array}$ & $*$ \\
\hline & $\begin{array}{l}\text { Creating a KM steering and advisory } \\
\text { committee consisting of a senior knowledge } \\
\text { manager, business executives and senior } \\
\text { business unit managers }\end{array}$ & $\begin{array}{l}\text { Kannabiran \& Pandyan (2010); Chen } \\
\text { \& Fong (2012); Schroeder et al. (2012) }\end{array}$ & $*$ \\
\hline & $\begin{array}{l}\text { Delegating authority for performing KM } \\
\text { activities }\end{array}$ & $\begin{array}{l}\text { Kannabiran \& Pandyan (2010); Chen } \\
\text { \& Fong (2012) }\end{array}$ & $*$ \\
\hline & $\begin{array}{l}\text { Developing KM-based performance } \\
\text { measurement system }\end{array}$ & $\begin{array}{l}\text { Schroeder et al. (2012); Dickel \& de } \\
\text { Moura (2016) }\end{array}$ & $*$ \\
\hline \multirow{4}{*}{$\begin{array}{l}\text { Top } \\
\text { management } \\
\text { support }\end{array}$} & $\begin{array}{l}\text { Facilitating the role of top management } \\
\text { regarding implementing KM }\end{array}$ & Hung et al. (2005); Migdadi (2009) & $*$ \\
\hline & $\begin{array}{l}\text { Top management trust about strategic use of } \\
\text { KM }\end{array}$ & & $*$ \\
\hline & $\begin{array}{l}\text { Top management commitment to prepare } \\
\text { sufficient resources }\end{array}$ & Migdadi (2009); Shanshan (2013) & $*$ \\
\hline & $\begin{array}{l}\text { Top management trust to KM executives and } \\
\text { team }\end{array}$ & $\begin{array}{l}\text { Hung et al. (2005); Al-Ammary } \\
\text { (2008); Hsieh et al. (2009) }\end{array}$ & $*$ \\
\hline \multirow[t]{3}{*}{$\begin{array}{l}\text { KM-business } \\
\text { communications }\end{array}$} & $\begin{array}{l}\text { Effective communication channels between } \\
\text { knowledge and business staff }\end{array}$ & $\begin{array}{l}\text { Hung et al. (2005); Huang \& Lai } \\
\text { (2012) }\end{array}$ & $*$ \\
\hline & Relationship between $\mathrm{CEO}$ and $\mathrm{CKO}$ & $\begin{array}{l}\text { Al-Ammary (2008); Ekionea \& Swain } \\
\text { (2008) }\end{array}$ & $*$ \\
\hline & $\begin{array}{l}\text { The existence of the feedback mechanisms } \\
\text { and reciprocal relations between business and }\end{array}$ & $\begin{array}{l}\text { Hsieh et al. (2009); Wang \& Chang } \\
\text { (2007) }\end{array}$ & $*$ \\
\hline
\end{tabular}




\begin{tabular}{|c|c|c|c|}
\hline \multirow[b]{2}{*}{$\begin{array}{l}\text { Competitive } \\
\text { conditions }\end{array}$} & $\begin{array}{l}\text { KM } \\
\text { Easy access to shared messages between KM } \\
\text { and business }\end{array}$ & $\begin{array}{l}\text { Wang \& Chang (2007); Dickel \& de } \\
\text { Moura (2016) }\end{array}$ & $*$ \\
\hline & $\begin{array}{l}\text { Growing technology market trend in } \mathrm{KM} \\
\text { systems }\end{array}$ & $\begin{array}{l}\text { Chan et al. (2006); } \\
\text { Al-Ammary (2008); Ekionea \& Swain } \\
\text { (2008) }\end{array}$ & $*$ \\
\hline \multirow{7}{*}{$\begin{array}{l}\text { Knowledge- } \\
\text { friendly culture }\end{array}$} & High maturity in KM industry & $\begin{array}{l}\text { Chan et al. (2006); Huang \& Lai } \\
\text { (2014) }\end{array}$ & $*$ \\
\hline & $\begin{array}{l}\text { Competitors' activities regarding KM } \\
\text { implementation }\end{array}$ & $\begin{array}{l}\text { Ekionea \& Swain (2008); Chan et al. } \\
\text { (2006) }\end{array}$ & $*$ \\
\hline & $\begin{array}{l}\text { Existence of high requirements for KM } \\
\text { systems in organization }\end{array}$ & $\begin{array}{l}\text { Ekionea \& Swain (2008); Chan et al. } \\
\text { (2006) }\end{array}$ & $*$ \\
\hline & $\begin{array}{l}\text { Employees' commitment towards knowledge } \\
\text { initiatives }\end{array}$ & $\begin{array}{l}\text { Wang \& Chang (2007); Hsieh et al. } \\
\text { (2009); Ekionea \& Swain (2008) }\end{array}$ & $*$ \\
\hline & Trust between business/KM staff & $\begin{array}{l}\text { Migdadi (2009); Hsieh et al. (2009); } \\
\text { Al-Ammary (2014) }\end{array}$ & $*$ \\
\hline & $\begin{array}{l}\text { Individuals' willingness towards continuous } \\
\text { learning }\end{array}$ & $\begin{array}{l}\text { Shanshan (2013); Wang \& Chang } \\
\text { (2007); Migdadi (2009) }\end{array}$ & $*$ \\
\hline & $\begin{array}{l}\text { Employees' inclination towards knowledge } \\
\text { sharing }\end{array}$ & $\begin{array}{l}\text { Shanshan (2013); Wang \& Chang } \\
\text { (2007); Hsieh et al. (2009); Ekionea \& } \\
\text { Swain (2008) }\end{array}$ & $*$ \\
\hline \multirow{4}{*}{$\begin{array}{l}\text { IT } \\
\text { sophistication }\end{array}$} & $\begin{array}{l}\text { Shared risks and rewards for business/KM } \\
\text { staff }\end{array}$ & $\begin{array}{l}\text { Migdadi (2009); Wang \& Chang } \\
\text { (2007) }\end{array}$ & $*$ \\
\hline & Developing IT architecture & $\begin{array}{l}\text { Shanshan (2013); Charoensuk et al. } \\
\text { (2014); Al-Ammary (2014) }\end{array}$ & $*$ \\
\hline & $\begin{array}{l}\text { Defining the role of IT in KM strategic } \\
\text { planning }\end{array}$ & Al-Ammary (2008); Shanshan (2013) & $*$ \\
\hline & $\begin{array}{l}\text { Adoption of KM technological mechanisms } \\
\text { (wikis, blogs, portals, etc.) }\end{array}$ & $\begin{array}{l}\text { Asoh (2004); Chen et al. (2012); Hsieh } \\
\text { et al. (2009) }\end{array}$ & $*$ \\
\hline \multirow{4}{*}{$\begin{array}{l}\text { Strategic } \\
\text { attitude towards } \\
\text { KM }\end{array}$} & Developing flexible KM infrastructure & $\begin{array}{l}\text { Abou-Zeid (2009); Ekionea \& Swain } \\
\text { (2008) }\end{array}$ & $*$ \\
\hline & Developing KM architecture & Asoh (2004); Akhavan et al (2009) & $*$ \\
\hline & $\begin{array}{l}\text { Defining the role of } \mathrm{KM} \text { in business strategic } \\
\text { planning }\end{array}$ & $\begin{array}{l}\text { Al-Ammary (2008); Asoh (2004); } \\
\text { Chan et al. (2006); Du Plessis (2007) }\end{array}$ & $*$ \\
\hline & $\begin{array}{l}\text { Participation of CEO and CKO in strategic } \\
\text { planning }\end{array}$ & Al-Ammary (2008); Du Plessis (2007) & $*$ \\
\hline \multirow{5}{*}{ Skills } & $\begin{array}{l}\text { Identifying strategic knowledge areas in } \\
\text { organizations }\end{array}$ & Asoh (2004); Zack (2002) & $*$ \\
\hline & $\begin{array}{l}\text { Employing experienced and knowledgeable } \\
\text { staff }\end{array}$ & $\begin{array}{l}\text { Dickel \& de Moura (2016); Akhavan et } \\
\text { al. (2009) }\end{array}$ & $*$ \\
\hline & Knowledge competency-based promotion & $\begin{array}{l}\text { Abou-Zeid (2009); Ekionea \& Swain } \\
\text { (2008) }\end{array}$ & $*$ \\
\hline & $\begin{array}{l}\text { Developing training programs to promote } \\
\text { staff's KM related skills }\end{array}$ & $\begin{array}{l}\text { Hsieh et al. (2009); Ekionea \& Swain } \\
\text { (2008) }\end{array}$ & $*$ \\
\hline & $\begin{array}{l}\text { Adopting KM non-technological mechanisms } \\
\text { (brainstorming, mentoring, storytelling, etc.) }\end{array}$ & $\begin{array}{l}\text { Abou-Zeid (2009); Chen et al. (2012); } \\
\text { Wang \& Chang (2007) }\end{array}$ & $*$ \\
\hline
\end{tabular}

Step 2. In this step, the factors and related measures extracted from the literature and qualitative focus group were evaluated and weighted by a survey method using a questionnaire. Before analyzing the collected data, it is necessary to ensure normality of the data and this can be accomplished by Kolmogorov-Smirnov test. The test results 
indicate that the variables are not normally distributed, and this led to analyzing the gathered data with nonparametric tests. In the rest of the section, it will be examined whether the factors and measures stated in the questionnaire are accepted by the experts or not. Table 3 shows the result of the sign test for "KM governance" for example.

The sign test was performed for all measures and among the proposed measures, all were accepted except "Delegating authority for performing KM activities" and "Developing IT architecture". This means that according to the experts, these two measures do not influence the KM strategic alignment. Therefore, they are omitted in the next phase of research.

\section{Table 3}

Results of sign test for "KM Governance"

\begin{tabular}{lccc}
\hline \multicolumn{1}{c}{ Measures } & Positive differences & Z-value & Conclusion \\
\hline $\begin{array}{l}\text { Definition of the role of knowledge chief } \\
\text { officer (CKO) in organization }\end{array}$ & 29 & 5.199 & Supported \\
$\begin{array}{l}\text { Establishment of the KM team or } \\
\text { organization }\end{array}$ & 25 & 4.234 & Supported \\
$\begin{array}{l}\text { Creating a KM steering and advisory } \\
\text { committee consisting of a senior knowledge } \\
\text { manager, business executives and senior } \\
\text { business unit managers }\end{array}$ & 31 & 5.388 & Supported \\
$\begin{array}{l}\text { Delegating authority for performing KM } \\
\text { activities }\end{array}$ & 14 & 0.453 & Rejected \\
$\begin{array}{l}\text { Developing KM-based performance } \\
\text { measurement system }\end{array}$ & 26 & 4.619 & Supported \\
\hline
\end{tabular}

To prioritize factors and their measures' weights, Shannon's entropy technique was used. Following equations were used to calculate measures weights:

$$
\begin{aligned}
& p_{i j}=\frac{a_{i j}}{\sum_{i=1}^{m} a_{i j}} \text { for } j=1, \ldots, n \\
& E_{j}=-k \sum_{i=1}^{m} p_{i j} \cdot \ln p_{i j} \quad \text { for } j=1, \ldots, n \text { where } k=\frac{1}{\ln (m)} \\
& d_{j}=1-E_{j} \quad \text { for } j=1, \ldots, n \\
& w_{j}=\frac{d_{j}}{\sum_{j=1}^{n} d_{j}}
\end{aligned}
$$

The results of Shannon's entropy are shown in Table 4.

Table 4

The result of prioritizing the factors and their measures

\begin{tabular}{clclc}
\hline Factors & Measures & $\mathrm{Ej}$ & $\mathrm{Wj}$ & $\mathrm{Rank}$ \\
\hline $\begin{array}{c}\text { KM } \\
\text { governance } \\
\text { (Weight: }\end{array}$ & $\begin{array}{l}\text { Definition of the role of knowledge } \\
\text { chief officer (CKO) in organization }\end{array}$ & 0.9937 & 0.1608 & 4 \\
0.12547, & $\begin{array}{l}\text { Establishment of the KM team or } \\
\text { organization }\end{array}$ & 0.9923 & 0.1970 & 3
\end{tabular}


rank:2)

Top
management
support
(Weight:
0.12498,
rank:5)

KM-business communication

(Weight:

0.12499 , rank:4)

Competitive conditions

(Weight:

0.12471 , rank:7)

Knowledgefriendly culture

(Weight:

0.15696 , rank:1)

IT sophisticatin

(Weight:

0.09308 ,
Creating a KM steering and advisory committee consisting of a senior knowledge manager, business executives and senior business unit managers

Developing KM-based performance measurement system

Facilitating role of top management regarding implementing $\mathrm{KM}$

Top management trust about strategic use of KM

Top management commitment to prepare sufficient resources

Top management trust to KM executives and team

Effective communication channels between knowledge and business staff

Relationship between CEO and CKO

Existence of the feedback mechanisms and reciprocal relations between business and KM

Easy access to shared messages between KM and business

Growing technology market trend in KM systems

High maturity in KM industry

Competitors 'Activities regarding KM implementation

Existence of high requirements for KM systems in organization

Employees' commitment towards knowledge initiatives

Trust between business/KM staff

Individuals' willingness towards continuous learning

Employees' inclination towards

knowledge sharing

Shared risks and rewards for business/KM staff

Defining the role of IT in KM strategic planning

Adoption of KM technological mechanisms (wikis, blogs, portals, etc.)
0.9917 0.2079 2

$\begin{array}{lll}0.9891 & 0.4341 & 1 \\ 0.9827 & 0.3178 & 1 \\ 0.9896 & 0.1905 & 4 \\ 0.9887 & 0.2085 & 3 \\ 0.9847 & 0.2822 & 2 \\ 0.9931 & 0.1271 & 4 \\ 0.9885 & 0.2130 & 3 \\ 0.97913 & 0.3873 & 1\end{array}$

$\begin{array}{lll}0.98532 & 0.27239 & 2\end{array}$

$0.9893 \quad 0.1703 \quad 4$

$\begin{array}{lll}0.9811 & 0.3005 \quad 2\end{array}$

$0.9811 \quad 0.3011 \quad 1$

$\begin{array}{lll}0.9857 & 0.2279 & 3\end{array}$

$\begin{array}{lll}0.9908 & 0.2047 \quad 2\end{array}$

$0.9914 \quad 0.1913 \quad 3$

$0.9919 \quad 0.1804 \quad 4$

$\begin{array}{lll}0.9957 & 0.0948 \quad 5\end{array}$

$\begin{array}{lll}0.9854 & 0.3269 & 1\end{array}$

$\begin{array}{lll}0.9730 & 0.4395 & 1\end{array}$

$0.9884 \quad 0.1877 \quad 3$




\begin{tabular}{|c|c|c|c|c|}
\hline rank:8) & Developing flexible KM infrastructure & 0.9771 & 0.3726 & 2 \\
\hline \multirow{4}{*}{$\begin{array}{c}\text { Strategic } \\
\text { attitude toward } \\
\text { KM } \\
\text { (Weight: } \\
0.125, \\
\text { rank:3) }\end{array}$} & Developing KM architecture & 0.9902 & 0.1826 & 4 \\
\hline & $\begin{array}{l}\text { Defining the role of } \mathrm{KM} \text { in business } \\
\text { strategic planning }\end{array}$ & 0.9876 & 0.2306 & 0 \\
\hline & $\begin{array}{l}\text { Participation of CEO and CKO in } \\
\text { strategic planning }\end{array}$ & 0.9884 & 0.2168 & 3 \\
\hline & $\begin{array}{l}\text { Identifying strategic knowledge areas } \\
\text { in organizations }\end{array}$ & 0.9802 & 0.3699 & 1 \\
\hline \multirow{4}{*}{$\begin{array}{l}\text { Skills (Weight: } \\
0.12478, \\
\text { rank:6) }\end{array}$} & $\begin{array}{l}\text { Employing experienced and } \\
\text { knowledgeable staff }\end{array}$ & 0.9784 & 0.4564 & 1 \\
\hline & $\begin{array}{l}\text { Knowledge competency-based } \\
\text { promotion }\end{array}$ & 0.9815 & 0.3064 & 2 \\
\hline & $\begin{array}{l}\text { Developing training programs to } \\
\text { promote staff's KM related skills }\end{array}$ & 0.9861 & 0.2292 & 3 \\
\hline & $\begin{array}{l}\text { Adopting KM non-technological } \\
\text { mechanisms (brainstorming, } \\
\text { mentoring, storytelling, etc.) }\end{array}$ & 0.9934 & 0.1078 & 4 \\
\hline
\end{tabular}

KM strategic alignment framework is shown in Fig. 1, which assists the organization to adopt a multi-dimensional view towards achieving KM alignment.

\section{Conclusions}

Benefits of knowledge investments can be best achieved when they support key business objectives and processes. The relationship between KM and business strategies is a key factor in successful KM implementation (Abou-Zeid, 2009; Ale et al., 2014). The purpose of this research is to identify and prioritize the effective factors influencing the strategic alignment of KM and business. After a comprehensive review of the literature, a framework for strategic alignment of KM was extracted. Then, experts' opinions were collected using a survey method and, finally, the analysis was made for evaluating factors and prioritizing them. Results of the analysis indicated that effective factors on strategic alignment of KM with business include knowledge-friendly culture, KM governance, strategic attitude towards KM, KM-business communications, top management support, skills, competitive conditions, and IT sophistication.

Based on these results, KM governance is an effective factor in achieving KM strategic alignment that is also pointed out by Abou-Zeid (2009). KM-business communications with such measures like the existence of the feedback mechanisms and reciprocal relations between business and KM, easy access to shared messages between $\mathrm{KM}$ and business, the relationship between CEO and CKO and effective communication channels between knowledge and business staff are other effective factors on KMbusiness strategic alignment. This result is consistent with previous works such as Luftman (2000), Charoensuk, Wongsurawat, and Khang (2014) and El-Mekawy et al. (2015) in the area of IS. Competitive conditions are also considered as an important factor in achieving KM-business alignment which is consistent with findings of the researches conducted by Chan, Sabherwal, and Thatcher (2006) in IS and Ekionea and Swine (2008) in KM. 
IT sophistication is another effective factor in KM-business strategic alignment. This result also is supported by the findings of Luftman (2000) and Charoensuk et al. (2014) in IS. Skills are found to be an effective factor of KM strategic alignment which it is consistent with the findings of Luftman (2000) in IS. Top management is an effective factor on strategic alignment of KM, which is also pointed out by El-Mekawy et al. (2015). Strategic attitude towards KM as mentioned by Asoh (2004) is considered as the most effective factor of KM alignment. Knowledge-friendly culture also is found to have a vital role in achieving KM strategic alignment which is also confirmed by Zack (2002).

\begin{tabular}{|c|c|c|c|}
\hline $\begin{array}{l}\text { Knowledge-friendly } \\
\text { culture }\end{array}$ & Skills & $\begin{array}{l}\text { Strategic attitude } \\
\text { toward } \mathrm{KM}\end{array}$ & $\begin{array}{c}\text { Top management } \\
\text { support }\end{array}$ \\
\hline $\begin{array}{l}\text { - Employees' } \\
\text { commitment towards } \\
\text { knowledge initiatives } \\
\text { - Trust between } \\
\text { business/KM staff } \\
\text { - Individuals } \\
\text { willingness towards } \\
\text { continuous learning } \\
\text { - Employees' } \\
\text { inclination towards } \\
\text { knowledge sharing } \\
\text { - Shared risks and } \\
\text { rewards for } \\
\text { business/KM staff }\end{array}$ & $\begin{array}{l}\text { - Employing } \\
\text { experienced and } \\
\text { knowledgeable staff } \\
\text { - Knowledge } \\
\text { competency-based } \\
\text { promotion } \\
\text { - Developing training } \\
\text { programs to promote } \\
\text { staff's km related skills } \\
\text { - Adopting KM non- } \\
\text { technological } \\
\text { mechanisms }\end{array}$ & $\begin{array}{l}\text { - Developing KM } \\
\text { architecture } \\
\text { - Participation of CEO } \\
\text { and CKO in strategic } \\
\text { planning } \\
\text { - Defining the role of } \\
\text { KM in business } \\
\text { strategic planning } \\
\text { - Identifying strategic } \\
\text { knowledge areas in } \\
\text { organizations }\end{array}$ & $\begin{array}{l}\text { - Facilitating role of top } \\
\text { management regarding } \\
\text { implement KM } \\
\text { - Top management trust } \\
\text { about strategic use of } \\
\text { KM } \\
\text { - Top management } \\
\text { commitment to prepare } \\
\text { sufficient resources } \\
\text { - Top management trust } \\
\text { to KM executives and } \\
\text { team }\end{array}$ \\
\hline \multicolumn{4}{|c|}{ KM-business strategic alignment } \\
\hline $\begin{array}{l}\text { Competitive } \\
\text { conditions }\end{array}$ & $\mathrm{KM}$ governance & IT sophistication & $\begin{array}{l}\text { KM-business } \\
\text { communications }\end{array}$ \\
\hline $\begin{array}{l}\text { - Growing technology } \\
\text { market trend in KM } \\
\text { systems } \\
\text { - High maturity in KM } \\
\text { industry } \\
\text { - Competitors } \\
\text { 'Activities regarding } \\
\text { KM implementation } \\
\text { - Existence high } \\
\text { requirements for KM } \\
\text { systems in organization }\end{array}$ & $\begin{array}{l}\text {-Definition the role of } \\
\text { knowledge chief officer } \\
\text { - Establish the KM } \\
\text { team or organization } \\
\text { - Creating a KM } \\
\text { steering and advisory } \\
\text { committee } \\
\text { - Develop KM-based } \\
\text { performance } \\
\text { measurement system }\end{array}$ & $\begin{array}{l}\text {-IT architecture } \\
\text { development } \\
\text { - Defining the role of IT } \\
\text { in KM strategic } \\
\text { planning } \\
\text { - Adoption of KM } \\
\text { technological } \\
\text { mechanisms } \\
\text { - Developing flexible } \\
\text { KM infrastructure }\end{array}$ & $\begin{array}{l}\text { - Effective } \\
\text { communication } \\
\text { channels between } \\
\text { knowledge and } \\
\text { business staff } \\
\text { - Relationship between } \\
\text { CEO and CKO } \\
\text { - Existence of the } \\
\text { feedback mechanisms } \\
\text { and reciprocal relations } \\
\text { between business and } \\
\text { KM } \\
\text { Easy access to shared } \\
\text { messages between KM } \\
\text { and business }\end{array}$ \\
\hline
\end{tabular}

Fig. 1. KM strategic alignment framework

\subsection{Implications and future studies}

The main contribution of this study is that it proposes a comprehensive framework of effective factors and measures on KM strategic alignment which is ignored in a strategic area of KM; this study also prioritizes the proposed factors and related measures. The proposed framework considers strategic factors in $\mathrm{KM}$ along with human, process and 
technological factors. Therefore, the research framework is comprehensive enough to be used in different organizations and industries. It is expected that by using the findings, businesses can respond to KM productivity paradox and use KM investments to achieve their organizational objectives. For future studies, it is recommended to examine the relationships between the effective factors on aligning KM strategies with statistical methods like SEM or regression. Another suggestion for future studies is to apply the proposed framework to evaluate the statue of an organization regarding KM strategic alignment drivers by using the case study method.

\section{ORCID}

Mona Jami Pour (iD https://orcid.org/0000-0002-9701-653X

Hasan Zarei Matin (D) https://orcid.org/0000-0001-5583-0675

Hamid Reza Yazdani (iD https://orcid.org/0000-0002-5957-643X

Zahra Kouchak Zadeh (D) https://orcid.org/0000-0002-0926-1130

\section{References}

Abou-Zeid, E. S. (2009). Alignment of business and knowledge management strategy. In M. Khosrow-Pour (Ed.), Encyclopedia of Information Science and Technology (2nd ed) (pp.124-129).

Abu Bakar, A. H., Yusof, M. N., Tufail, M. A., \& Virgiyanti, W. (2016). Effect of knowledge management on growth performance in construction industry. Management Decision, 54(3), 735-749.

Akhavan, P., Hosnavi, R., \& Sanjaghi, M. E. (2009). Identification of knowledge management critical success factors in Iranian academic research centers. Education, Business and Society: Contemporary Middle Eastern Issues, 2(4), 276-288.

Akhavan, P., Reza Zahedi, M., \& Hosein Hosein, S. (2014). A conceptual framework to address barriers to knowledge management in project-based organizations. Education, Business and Society: Contemporary Middle Eastern Issues, 7(2/3), 98-119.

Akram, K., Mehmood, N., \& Khan, I. (2015). A conceptual linkage between knowledge management, competitive advantage and competitive maneuverings of organizations. International Journal of Scientific and Research Publications, 5(2), 605-610.

Aktürk, B. K., \& Kurt, M. (2016). An empirical study of the relationship between knowledge management practices and strategy formulation capabilities. ProcediaSocial and Behavioral Sciences, 235, 739-745.

Alaceva, C., \& Rusu, L. (2015). Barriers in achieving business/IT alignment in a large Swedish company: What we have learned? Computers in Human Behavior, 51(Part B), 715-728.

AlAmmary, J., \& Fung, C. C. (2008). Knowledge management strategic alignment in the Gulf Cooperation Council countries. The Electronic Journal of Knowledge Management, 6(2), 75-84.

Ale, M. A., Toledo, C. M., Chiotti, O., \& Galli, M. R. (2014). A conceptual model and technological support for organizational knowledge management. Science of Computer Programming, 95(Part 1), 73-92.

Al-Ammary, J. (2014). The strategic alignment between knowledge management and information systems strategy: The impact of contextual and cultural factors. Journal of Information \& Knowledge Management, 13(01): 1450006. 
Al-Ammary, J. H. (2008). Knowledge management strategic alignment in the banking sector at the Gulf Cooperation Council (GCC) countries. Doctoral dissertation, Murdoch University, AU. Retrieved from http://researchrepository.murdoch.edu.au/id/eprint/433/2/02Whole.pdf

APQC. (2015). How companies spend on knowledge management. Retrieved from https://www.apqc.org/knowledge-base/download/350193/K06113_KM budget.pdf

Asoh, D. A., Belardo, S., \& Duchessi, P. (2008). Knowledge strategic alignment: Research framework, models, and concepts. In E. S. Abou-Zeid (Ed.), Knowledge Management and Business Strategies: Theoretical Frameworks and Empirical Research (pp. 188-208). IGI Global.

Asoh, D. A. (2004). Business and knowledge strategies: Alignment and performance impact analysis. Doctoral dissertation, State University of New York at Albany, USA.

Beiryaei, H. S., \& Jamporazmay, M. (2010, August). Propose a framework for knowledge management strategic planning (KMSSP). In Proceedings of the International Conference on Electronics and Information Engineering. IEEE.

Bosua, R., \& Venkitachalam, K. (2013). Aligning strategies and processes in knowledge management: A framework. Journal of Knowledge Management, 17(3), 331-346.

Centobelli, P., Cerchione, R., \& Esposito, E. (2018). Aligning enterprise knowledge and knowledge management systems to improve efficiency and effectiveness performance: A three-dimensional fuzzy-based decision support system. Expert Systems with Applications, 91, 107-126.

Chan, Y. E., Sabherwal, R., \& Thatcher, J. B. (2006). Antecedents and outcomes of strategic IS alignment: An empirical investigation. IEEE Transactions on Engineering Management, 53(1), 27-47.

Chang, C. L. H., \& Lin, T. C. (2015). The role of organizational culture in the knowledge management process. Journal of Knowledge Management, 19(3), 433-455.

Charoensuk, S., Wongsurawat, W., \& Khang, D. B. (2014). Business-IT alignment: A practical research approach. The Journal of High Technology Management Research, 25(2), 132-147.

Chen, L., \& Fong, P. S. W. (2012). Revealing performance heterogeneity through knowledge management maturity evaluation: A capability-based approach. Expert Systems with Applications, 39(18), 13523-13539.

Chen, Y. Y., \& Huang, H. L. (2010). The knowledge management strategic alignment model (KMSAM) and its impact on performance: An empirical examination. IntechOpen.

Chen, Y. Y., \& Huang, H. L. (2012). Knowledge management fit and its implications for business performance: A profile deviation analysis. Knowledge-Based Systems, 27, 262-270.

Chen, Y. Y., Huang, H. L., \& Liu, T. P. (2007). An empirical investigation of the knowledge management strategic alignment model. In Proceedings of the IEEE International Conference on Industrial Engineering and Engineering Management (pp. 1965-1969). IEEE.

Chen, Y. Y., Yeh, S. P., \& Huang, H. L. (2012). Does knowledge management "fit" matter to business performance? Journal of Knowledge Management, 16(5), 671-687.

Chioncel, N. E., Van Der Veen, R. G. W., Wildemeersch, D., \& Jarvis, P. (2003). The validity and reliability of focus groups as a research method in adult education. International Journal of Lifelong Education, 22(5), 495-517.

Choe, J. (2014). The product and process innovations through the strategic alignment of knowledge management. Asian Journal of Technology Innovation, 22(1), 1-15.

Coltman, T., Tallon, P., Sharma, R., \& Queiroz, M. (2015). Strategic IT alignment: Twenty-five years on. Journal of Information Technology, 30(2), 91-100. 
Davenport, T. H., \& Prusak, L. (1998). Working knowledge: How organizations manage what they know. Harvard Business Press.

Dayan, R., Heisig, P., \& Matos, F. (2017). Knowledge management as a factor for the formulation and implementation of organization strategy. Journal of Knowledge Management, 21(2), 308-329.

Dickel, D. G., \& de Moura, G. L. (2016). Organizational performance evaluation in intangible criteria: A model based on knowledge management and innovation management. RAI Revista de Administração e Inovação, 13(3), 211-220.

Du Plessis, M. (2007). Knowledge management: What makes complex implementations successful? Journal of Knowledge Management, 11(2), 91-101.

Ekionea, J. P. B., \& Swain, D. E. (2008). Developing and aligning a knowledge management strategy: Towards a taxonomy and a framework. International Journal of Knowledge Management (IJKM), 4(1), 29-45.

El-Mekawy, M., Rusu, L., \& Perjons, E. (2015). An evaluation framework for comparing business-IT alignment models: A tool for supporting collaborative learning in organizations. Computers in Human Behavior, 51(Part B), 1229-1247.

Emerson, L. C., \& Berge, Z. L. (2018). Microlearning: Knowledge management applications and competency-based training in the workplace. Knowledge Management \& E-Learning, 10(2), 125-132.

Franken, A., \& Braganza, A. (2006). Organizational forms and knowledge management: One size fits all? International Journal of Knowledge Management Studies, 1(1/2), $18-37$.

Gable, G. (2010). Strategic information systems research: An archival analysis. The Journal of Strategic Information Systems, 19(1), 3-16.

Grant, R. M. (1996). Toward a knowledge-based theory of the firm. Strategic Management Journal, 17(S2), 109-122.

Guo, Z., \& Sheffield, J. (2008). A paradigmatic and methodological examination of knowledge management research: 2000 to 2004. Decision Support Systems, 44(3), $673-688$.

Henderson, J. C., \& Venkatraman, H. (1993). Strategic alignment: Leveraging information technology for transforming organizations. IBM Systems Journal, 32(1), $472-484$.

Hsieh, P. J., Lin, B., \& Lin, C. (2009). The construction and application of knowledge navigator model $\left(\mathrm{KNM}^{\mathrm{TM}}\right)$ : An evaluation of knowledge management maturity. Expert Systems with Applications, 36(2, Part 2), 4087-4100.

Huang, L. S., \& Lai, C. P. (2012). An investigation on critical success factors for knowledge management using structural equation modelling. Procedia-Social and Behavioral Sciences, 40, 24-30.

Huang, L. S., \& Lai, C. P. (2014). Critical success factors for knowledge management implementation in life insurance enterprises. International Journal of Management and Marketing Research, 7(2), 79-89.

Hung, Y. C., Huang, S. M., Lin, Q. P., \& Tsai, M. L. (2005). Critical factors in adopting a knowledge management system for the pharmaceutical industry. Industrial Management \& Data Systems, 105(2), 164-183.

Hussin, H., King, M., \& Cragg, P. (2002). IT alignment in small firms. European Journal of Information Systems, 11(2), 108-127.

Jami Pour, M., Kouchak Zadeh, Z., \& Ahmad Zadeh, N. (2018). Designing an integrated methodology for knowledge management strategic planning: The roadmap toward strategic alignment. VINE Journal of Information and Knowledge Management Systems, 48(3), 373-387.

Jami Pour, M., Manian, A., \& Yazdani, H. R. (2016). A theoretical and methodological examination of knowledge management maturity models: A systematic review. 
International Journal of Business Information Systems, 23(3), 330-352.

Jamporazmey, M., \& Mehrafrouz, M. (2012). Designing an evaluation framework for knowledge management systems by using balanced scorecard. International Journal of Business Information Systems, 11(1), 110-125.

Jennex, M. E., \& Olfman, L. (2010). A model of knowledge management success. In M. E. Jennex \& S. Smolnik (Eds.), Strategies for Knowledge Management Success. Exploring Organizational Efficacy (pp. 14-31). IGI Global.

Johnson, A. M., \& Lederer, A. L. (2010). CEO/CIO mutual understanding, strategic alignment, and the contribution of IS to the organization. Information \& Management, 47(3), 138-149.

Jorfi, S., \& Jorfi, H. (2011). Strategic operations management: Investigating the factors impacting IT-business strategic alignment. Procedia-Social and Behavioral Sciences, 24, 1606-1614.

Kannabiran, G., \& Pandyan, C. (2010). Enabling role of governance in strategizing and implementing KM. Journal of Knowledge Management, 14(3), 335-347.

Kekwaletswe, R. M., \& Mathebula, P. C. (2014). Aligning information systems strategy with the business strategy in a South African banking environment. In Proceedings of the Conference for Information Systems Applied Research. Baltimore, MD, USA.

Lee, S. M., Kim, K., Paulson, P., \& Park, H. (2008). Developing a socio-technical framework for business-IT alignment. Industrial Management \& Data Systems, 108(9), 1167-1181.

López-Nicolás, C., \& Meroño-Cerdán, Á. L. (2011). Strategic knowledge management, innovation and performance. International Journal of Information Management, 31(6), 502-509.

Luftman, J. (2000). Assessing business-IT alignment maturity. Communications of AIS, 4: 14.

Luftman, J., Zadeh, H. S., Derksen, B., Santana, M., Rigoni, E. H., \& Huang, Z. D. (2013). Key information technology and management issues 2012-2013: An international study. Journal of Information Technology, 28(4), 354-366.

Marques, J. M. R., La Falce, J. L., Marques, F. M. F. R., De Muylder, C. F., \& Silva, J. T. M. (2019). The relationship between organizational commitment, knowledge transfer and knowledge management maturity. Journal of Knowledge Management, 23(3), 489-507.

Massey, O. T. (2011). A proposed model for the analysis and interpretation of focus groups in evaluation research. Evaluation and Program Planning, 34(1), 21-28.

Migdadi, M. (2009). Knowledge management enablers and outcomes in the small-andmedium sized enterprises. Industrial Management \& Data Systems, 109(6), 840-858.

Preston, R. (2014). CIO worries: Security, talent and (sadly) 'alignment'. InformationWeek.

Rhem, A. J. (2015). Why do knowledge management (KM) programs and projects Fail? KM Institute. Retrieved from https://www.kminstitute.org/blog/why-do-knowledgemanagement-km-programs-and-projects-fail

Schroeder, A., Pauleen, D., \& Huff, S. (2012). KM governance: The mechanisms for guiding and controlling KM programs. Journal of Knowledge Management, 16(1), 321.

Shafiei Nikabadi, M., Bagheri, S., \& Mohammadi-Hoseini, S. A. (2016). Effects of knowledge management strategy and organizational learning capability on innovation-driven performance in an oil company. Knowledge Management \& ELearning, 8(2), 334-355.

Shanshan, S. (2013). The method of selecting critical successful factors to knowledge management and its automation. Journal of Theoretical \& Applied Information 
Technology, 49(1), 433-441.

Shih, H. A., \& Chiang, Y. H. (2005). Strategy alignment between HRM, KM, and corporate development. International Journal of Manpower, 26(6), 582-603.

Smith, T. A., Mills, A. M., \& Dion, P. (2010). Linking business strategy and knowledge management capabilities for organizational effectiveness. International Journal of Knowledge Management (IJKM), 6(3), 22-43.

Tessier, D., \& Dalkir, K. (2016). Implementing moodle for e-learning for a successful knowledge management strategy. Knowledge Management \& E-Learning, 8(3), 414429.

Tseng, S. M. (2008). Knowledge management system performance measure index. Expert Systems with Applications, 34(1), 734-745.

Turner, J. M., Biros, D. P., \& Moseley, M. W. (2009). "KMS-Fit": A case-based exploration of task/technology fit in an applied knowledge management context. Knowledge Management \& E-Learning, 1(2), 120-138.

Walsh, I., \& Renaud, A. (2017). Reviewing the literature in the IS field: Two bibliometric techniques to guide readings and help the interpretation of the literature. Systèmes d'information \& management, 22(3), 75-115.

Wang, J., Ding, D., Liu, O., \& Li, M. (2016). A synthetic method for knowledge management performance evaluation based on triangular fuzzy number and group support systems. Applied Soft Computing, 39, 11-20.

Wang, T. C., \& Chang, T. H. (2007). Application of consistent fuzzy preference relations in predicting the success of knowledge management implementation. European Journal of Operational Research, 182(3), 1313-1329.

Wu, C., Chen, Y., Fang, W., \& Sung, S. (2015). The knowledge management strategic alignment model (KMSAM) a holistic perspective. International Journal of Engineering and Technical Research (IJETR), 3(10), 106-115.

Yaghmale, F. (2009). Content validity and its estimation. Journal of Medical Education, $3(1): 5$.

Zack, M. H. (2002). Developing a knowledge strategy. In C. W. Choo \& N. Bontis (Eds.), The Strategic Management of Intellectual Capital and Organizational Knowledge. Oxford University Press.

Zhao, M., Qiu, W., \& Liu, B. (2010). Relative entropy evaluation method for multiple attribute decision making. Control and Decision, 25(7), 1098-1100.

Zion Market Research. (2018). Knowledge management market to record impressive growth, revenue to surge to US\$1,232,000 million by 2025. Retrieved from https://www.zionmarketresearch.com/news/knowledge-management-market 